Małgorzata Bajor-Stachańczyk

\title{
Możliwość wyboru metody ustalania opłaty za gospodarowanie odpadami komunalnymi ${ }^{1}$
}

\author{
Choosing the method for determining the communal waste \\ management fee
}

The Act on Maintaining Cleanliness and Order in Communes provides the basis for choosing the method of determining the fee based on several criteria. It also states that a communal council may apply various criteria differentiating the rates of payment. According to the current case law of the Supreme Administrative Court, the communal council has no right to introduce an additional criterion - within the chosen method of determining the fee - i.e. a division of households into categories depending on the number of tenants. Though, it cannot be excluded that there is a possibility to differentiate the fee calculated as a product of the number of tenants in the given real estate and the sum of the fee when applying the number of tenants as a criterion of differentiation. It has to be stressed that the stance of acceptance of such differentiation may be questioned by supervisory authorities.

Keywords: commune, waste, fee

Ustawa o utrzymaniu czystości i porządku w gminach daje podstawę do wyboru metody ustalenia opłaty według kilku kryteriów. Postanawia również, że rada gminy może stosować łącznie kilka kryteriów różnicujących stawki opłaty. Zgodnie z aktualnym orzecznictwem Naczelnego Sądu Administracyjnego brak upoważnienia dla rady gminy do wprowadzenia dodatkowego kryterium - w ramach wybranej metody ustalania opłaty - jakim jest podział gospodarstw domowych na kategorie zależne od liczby osób w nich zamieszkujących. Nie można natomiast wykluczyć możliwości zróżnicowania opłaty stanowiącej iloczyn liczby mieszkańców danej nieruchomości i stawki opłaty przy zastosowaniu liczby mieszkańców jako kryterium zróżnicowania. Należy jednak podkreślić, że stanowisko dopuszczające zróżnicowanie stawki z uwzględnieniem tego kryterium może być kwestionowane przez organy nadzoru.

Słowa kluczowe: gmina, odpady, opłaty

Ekspert ds. legislacji Biura Analiz Sejmowych •

Kancelaria Sejmu, Biuro Analiz Sejmowych, Wydział Analiz Prawnych, Zespół Prawa

Publicznego, WARSZAWA, POLSKA .

malgorzata.bajor-stachanczyk@sejm.gov.pl • https://orcid.org/0000-0003-0952-281X

\section{Przedmiot opinii}

W opinii przedstawiono odpowiedź na pytanie o ocenę dopuszczalności, na gruncie przepisów ustawy z 13 września 1996 r. o utrzymaniu czystości i porząd-

1 Opinia prawna w sprawie możliwości wyboru metody ustalania opłaty za gospodarowanie odpadami komunalnymi sporządzona 24 lutego 2020 r. na zlecenie posła Klubu Parlamentarnego Klub Parlamentarny Koalicja Obywatelska - Platforma Obywatelska, Nowoczesna, Inicjatywa Polska, Zieloni; BAS-WAP 244/20. 
ku w gminach, wyboru metody ustalania opłaty za gospodarowanie odpadami komunalnymi uzależnionej od liczby mieszkańców zamieszkujących daną nieruchomość przy uwzględnieniu założenia, że za każdą kolejną osobę zamieszkującą daną nieruchomość naliczana będzie niższa opłata, przy czym pojęcie „nieruchomość” w przypadku zabudowy wielorodzinnej (wielolokalowej) rozumiane będzie jako lokal mieszkalny. Należy podkreślić, że interpretacja przepisów w tym zakresie jest zróżnicowana i sprzeczna.

W niniejszej opinii uwzględniono stan prawny na dzień jej sporządzenia następujących postanowień:

- ustawy z 13 września 1996 r. o utrzymaniu czystości i porządku w gminach, t.j. Dz.U. 2019, poz. 2010, ze zm.; dalej: ustawa albo u.c.p.g.,

- ustawy z 8 marca 1990 r. o samorządzie gminnym, t.j. Dz.U. 2019, poz. 506, ze zm.; dalej: u.s.gm.

\section{Uzasadnienie}

Zadania gminy oraz obowiązki właścicieli nieruchomości dotyczące utrzymania czystości i porządku, w tym zasady ustalania opłat ponoszonych za gospodarowanie odpadami komunalnymi, reguluje ustawa o utrzymaniu czystości i porządku w gminach. Zgodnie z jej przepisami gminy są obowiązane do zorganizowania odbierania odpadów komunalnych od właścicieli nieruchomości, na których zamieszkują mieszkańcy (art. $6 c$ ust. 1 u.c.p.g.), a właściciele nieruchomości są obowiązani ponosić na rzecz gminy, na terenie której są położone ich nieruchomości, opłatę za gospodarowanie odpadami komunalnymi (art. $6 \mathrm{~h}$ u.c.p.g.). $\mathrm{W}$ art. $6 \mathrm{j}$ ustawa przewiduje różne metody ustalania opłaty za gospodarowanie odpadami komunalnymi w przypadku nieruchomości, o której mowa w art. $6 \mathrm{c}$ ust. 1. Pierwszą metodę wskazuje art. $6 \mathrm{j}$ ust. 1, zgodnie z którym opłata za gospodarowanie odpadami komunalnymi stanowi iloczyn:

- liczby mieszkańców zamieszkujących daną nieruchomość lub

- ilości zużytej wody z danej nieruchomości, lub

- powierzchni lokalu mieszkalnego

oraz stawki opłaty ustalonej na podstawie art. $6 \mathrm{k}$ ust. 1 u.c.p.g.

Drugą metodę reguluje art. $6 \mathrm{j}$ ust. 2, który wskazuje, że rada gminy może uchwalić jedną stawkę opłaty za gospodarowanie odpadami komunalnymi od gospodarstwa domowego.

Wyboru metody ustalenia opłaty za gospodarowanie odpadami komunalnymi spośród metod określonych w art. 6j ust. 1 i 2 u.c.p.g., ustalenia stawki takiej opłaty oraz ustalenia stawki opłaty za pojemnik lub worek o określonej pojemności, przeznaczony do zbierania odpadów komunalnych na terenie nieruchomości, dokonuje rada gminy w drodze uchwały (art. 6k ust. 1 ustawy). Uchwała rady 
gminy zawierająca wskazane regulacje jest aktem prawa miejscowego w rozumieniu art. 40 ust. 1 u.s.gm. Przy wydawaniu takiej uchwały rada ma obowiązek uwzględnić: liczbę mieszkańców zamieszkujących daną gminę, ilość wytwarzanych na terenie gminy odpadów komunalnych, koszty funkcjonowania systemu gospodarowania odpadami komunalnymi oraz przypadki, w których właściciele nieruchomości wytwarzają odpady nieregularnie, w szczególności to, że na niektórych nieruchomościach odpady komunalne powstają sezonowo. Ustawa dopuszcza stosowanie więcej niż jednej metody ustalenia opłat na obszarze gminy.

Zgodnie z art 6j ust. 1 u.c.p.g. opłata stanowi iloczyn stawki ustalonej na podstawie art. 6k ust. 1 oraz wybranej zmiennej (liczba mieszkańców, ilość zużytej wody, powierzchnia lokalu). Metoda ta (czy też, według niektórych, trzy metody) przewiduje więc ustalenie jednej stawki za gospodarowanie odpadami, a następnie uzależnienie wysokości opłat od okoliczności wskazanych w pkt 1-3 (art. 6j ust. 1). Z kolei art. 6j ust. 2 pozwala na uchwalenie jednej stawki opłaty za gospodarowanie odpadami komunalnymi od gospodarstwa domowego, bez względu na liczebność takiego gospodarstwa. Regulację tę uzupełnia art. 6j ust. 2a ustawy, który daje podstawę do zróżnicowania stawki opłaty w zależności od powierzchni lokalu mieszkalnego, liczby mieszkańców zamieszkujących nieruchomość, odbierania odpadów z terenów wiejskich lub miejskich, a także od rodzaju zabudowy. Postanawia również, że rada gminy może też stosować łącznie różne kryteria różnicujące stawki opłaty.

Powstaje w związku z tym pytanie, czy możliwość różnicowania stawek opłat za gospodarowanie odpadami komunalnymi wyrażona przez ustawodawcę w art. 6j ust. 2 u.c.p.g. dotyczy obu metod. W razie odpowiedzi twierdzącej, dopuszczalna byłaby koncepcja różnicowania stawki ze względu na liczbę osób stanowiących dane gospodarstwo domowe. Taki sposób rozumienia przepisu art. 6 j ust. 2a zdanie drugie jest jednak kwestionowany przez organy nadzoru oraz sądy administracyjne ${ }^{2}$. Zgodnie $z$ tym stanowiskiem ustawodawca w pierwszej kolejności uregulował w art. 6j ust. 1 i 2 u.c.p.g. metody ustalania opłat za gospodarowanie odpadami komunalnymi, a następnie wprowadził możliwość zróżnicowania stawki opłaty, ale z zawartych w tej regulacji sformułowań wynika, że odnosi się ona jedynie do metody wskazanej w art. 6j ust. 1, za pomocą kryteriów wskazanych w art. 6j ust. 2a ustawy. W konsekwencji możliwość różnicowania stawek opłat za gospodarowanie odpadami komunalnymi wyrażona przez ustawodawcę w art. 6j ust. 2a u.c.p.g. nie dotyczyłaby metody od gospodarstwa domowego. Takie stanowisko zaprezentował w szczególności Naczelny Sąd Administracyjny (NSA) w wyroku z 6 maja 2016 r., w sprawie o sygn akt II FSK 16/16. NSA podkreślił, że ze sformułowania art. 6j ust. 2a u.c.p.g. wyni-

2 Zob. uchwała Regionalnej Izby Obrachunkowej we Wrocławiu z 17 stycznia 2018 r., 5/2018; wyrok Wojewódzkiego Sądu Administracyjnego w Łodzi z 29 listopada 2016 r., sygn akt I SA/Łd 856/16, Legalis. 
ka, iż możliwość zróżnicowania stawki odnosi się tylko do niektórych parametrów obliczania opłaty, takich jak liczba mieszkańców czy powierzchnia lokalu, a więc tych, o których mowa w art. 6j ust. 1 u.c.p.g., nie odnosi się natomiast do metody uregulowanej w art. 6j ust. 2. Zdaniem NSA z żadnego przepisu prawa nie wynika upoważnienie dla rady gminy do wprowadzenia w ramach metody wymienionej w art. 6j ust. 2 u.c.p.g. dodatkowego kryterium, jakim jest podział gospodarstw domowych na kategorie zależne od liczby osób w nich zamieszkujących i zróżnicowanie na tej podstawie wysokości stawki opłaty.

Cytowany wyrok stanowił odejście od linii orzeczniczej NSA, zgodnie z którą, przy zastosowaniu wykładni celowościowej i funkcjonalnej, takie zróżnicowanie uznawano za dopuszczalne ${ }^{3}$. NSA uzasadnił to odejście zmianą przepisów ustawy ${ }^{4}$, a konkretnie zmianą przez ustawodawcę treści art. 6k ust. 4 ustawy, który w brzmieniu obowiązującym do dnia 31 stycznia 2015 r., umożliwiał radzie gminy, określającej warunki opłat zgodnie $\mathrm{z}$ metodą, o której mowa w art. 6j ust. 1 i 2 u.c.p.g., różnicowanie stawki opłat, wprowadzanie zwolnień przedmiotowych, ustanawianie dopłaty dla właścicieli nieruchomości, o których mowa w art. $6 \mathrm{c}$ ust. 1, spełniających ustalone przez nią kryteria, lub określanie szczegółowo zasady ustalania tych opłat.

Wnioskując z przedstawionego wyżej stanowiska NSA, koncepcja zróżnicowania opłat ze względu na liczbę osób stanowiących dane gospodarstwo domowe nie jest dopuszczalna. Pytanie przedstawione we wstępie opinii dotyczy jednak wyboru metody ustalania opłaty za gospodarowanie odpadami komunalnymi uzależnionej od liczby mieszkańców zamieszkujących daną nieruchomość w taki sposób, że za każdą kolejną osobę zamieszkującą daną nieruchomość naliczana będzie niższa opłata, przy czym pojęcie „nieruchomość” w przypadku zabudowy wielorodzinnej (wielolokalowej) rozumiane będzie jako lokal mieszkalny. Taka metoda ustalenia opłaty odwoływałaby się nie do pojęcia gospodarstwa domowego, ale do metody wskazanej w art. 6j ust. 1 pkt 1 u.c.p.g. W powołanym wyroku NSA w sprawie o sygn. akt II FSK 16/16 zaznaczył, że możliwość zróżnicowania stawki opłaty, o której mowa w art. 6j ust. 2a u.c.p.g., odnosi się tylko do metody wskazanej w art. 6j ust. 1 u.c.p.g. oraz, że nie można utożsamiać pojęcia „liczby mieszkańców zamieszkujących daną nieruchomość” z pojęciem "gospodarstwa domowego". NSA nie odniósł się wprost do możliwości zróżnicowania opłaty na podstawie kryterium liczby mieszkańców, wskazanego w art. 6j ust. 2a u.c.p.g. przy wyborze metody wskazanej w art. 6j ust. 1, niemniej wydaje się, że taka koncepcja byłaby uprawniona. Art. 6j ust. 2a ustawy, który daje podstawę do

3 Zob. wyrok NSA z 22 stycznia 2016 r., sygn. akt II FSK 3231/15, Legalis; wyrok Wojewódzkiego Sądu Administracyjnego w Rzeszowie z 9 lipca 2015 r., sygn. akt I SA/Rz 499/15, Legalis.

4 Zmiana art. 6k została dokonana nowelizacją z 28 listopada 2014 r., obowiązującą od dnia 1 lutego 2015 r., Dz.U. 2015, poz. 87. 
zróżnicowania stawki opłaty w zależności od powierzchni lokalu mieszkalnego, liczby mieszkańców zamieszkujących nieruchomość, odbierania odpadów z terenów wiejskich lub miejskich, a także od rodzaju zabudowy odnosi się, zgodnie ze stanowiskiem NSA, do metody określonej w art. 6j ust. 1. Postanawia również, że rada gminy może również stosować łącznie różne kryteria różnicujące stawki opłaty. Należy jednak podkreślić, że stanowisko dopuszczające takie zróżnicowanie może być kwestionowane jako rozwiązanie regulujące sposób ustalenia opłaty odmiennie niż wynika to z przepisów ustawy ${ }^{5}$.

\section{Podsumowanie}

- Na podstawie art. 6j ust. 1 pkt 1 u.c.p.g. jedną z metod ustalenia opłaty za gospodarowanie odpadami komunalnymi jest metoda, w której opłata stanowi iloczyn liczby mieszkańców zamieszkujących daną nieruchomość lub ilości zużytej wody z danej nieruchomości, lub powierzchni lokalu mieszkalnego oraz stawki opłaty ustalonej na podstawie art. 6k ust. 1 u.c.p.g. Inną metodą jest możliwość ustalenia jednej stawki opłaty za gospodarowanie odpadami komunalnymi od gospodarstwa domowego (art. 6 j ust. 2 u.c.p.g.).

- Artykuł 6j ust. 2a u.c.p.g. daje podstawę do zróżnicowania stawki opłaty w zależności od powierzchni lokalu mieszkalnego, liczby mieszkańców zamieszkujących nieruchomość, odbierania odpadów z terenów wiejskich lub miejskich, a także od rodzaju zabudowy. Postanawia również, że rada gminy może też stosować łącznie różne kryteria różnicujące stawki opłaty.

- Zgodnie z aktualnym orzecznictwem NSA brak upoważnienia dla rady gminy do wprowadzenia $w$ ramach metody wymienionej w art. $6 j$ ust. 2 u.c.p.g. dodatkowego kryterium, jakim jest podział gospodarstw domowych na kategorie zależne od liczby osób w nich zamieszkujących i zróżnicowanie na tej podstawie wysokości stawki opłaty.

- Wydaje się, że nie można wykluczyć możliwości zróżnicowania opłaty, o której mowa w art. 6j ust. 1 pkt 1 u.c.p.g., czyli opłaty stanowiącej iloczyn liczby mieszkańców danej nieruchomości i stawki opłaty przy zastosowaniu liczby mieszkańców jako kryterium zróżnicowania stawki (art. 6ust. 2a u.c.p.g.). Należy jednak podkreślić, że stanowisko dopuszczające takie zróżnicowanie może być kwestionowane przez organy nadzoru.

5 Zob. uchwała nr 11/2019 r. Regionalnej Izby Obrachunkowej we Wrocławiu z 30 października 2019 r., https://bip.wroclaw.rio.gov.pl/dokumenty/uchwaly/2019/1111905 052.pdf. 